\title{
Control of ventricular ciliary beating by the melanin concentrating hormone-expressing neurons of the lateral hypothalamus: a functional imaging survey
}

\section{Grégory Conductier ${ }^{1,2+}{ }^{\text {, Agnès O. Martin }}{ }^{3,4,5 t}{ }^{+}$, Pierre-Yves Risold ${ }^{6 \dagger}$, Sonia Jego ${ }^{7}$, Raphaël Lavoie ${ }^{7}$, Chrystel Lafont ${ }^{3,4,5}$, Patrice Mollard ${ }^{3,4,5 \neq}$, Antoine Adamantidis ${ }^{7 \neq}$ and Jean-Louis Nahon ${ }^{1,2,8 * \neq}$}

\author{
1 UMR7275, Institut de Pharmacologie Moléculaire et Cellulaire, Centre National de la Recherche Scientifique, Valbonne, France \\ 2 University of Nice Sophia Antipolis, Nice, France \\ ${ }^{3}$ UMR5203, Institut de Génomique Fonctionnelle, Centre National de la Recherche Scientifique, Montpellier, France \\ ${ }^{4}$ U661, INSERM, Montpellier, France \\ ${ }^{5}$ UMR-5203, Universités de Montpellier 1 \& 2, Montpellier, France \\ 6 Laboratoire d'Histologie, IFR 133, Faculté de Médecine et de Pharmacie, Besançon, France \\ 7 Douglas Mental Health University Institute, Montreal, OC, Canada \\ ${ }^{8}$ Station de Primatologie, UPS 846, Centre National de la Recherche Scientifique, Rousset sur Arc, France
}

\section{Edited by:}

Hubert Vaudry, University of Rouen,

France

\section{Reviewed by:}

Gert Jansen, Erasmus Medical

Centre, Netherlands

Serge H. Luquet, University Paris

Diderot, France

\section{*Correspondence:}

Jean-Louis Nahon, UMR7275, Institut de Pharmacologie Moléculaire et

Cellulaire, Centre National de la Recherche Scientifique, 660 Route des Lucioles, Sophia Antipolis, Valbonne, France

e-mail: nahonj|@ipmc.cnrs.fr

${ }^{+}$Co-Authors

${ }^{\ddagger}$ Co-Directors
The cyclic peptide Melanin Concentrating Hormone $(\mathrm{MCH})$ is known to control a large number of brain functions in mammals such as food intake and metabolism, stress response, anxiety, sleep/wake cycle, memory, and reward. Based on neuro-anatomical and electrophysiological studies these functions were attributed to neuronal circuits expressing $\mathrm{MCHR} 1$, the single $\mathrm{MCH}$ receptor in rodents. In complement to our recently published work (1) we provided here new data regarding the action of $\mathrm{MCH}$ on ependymocytes in the mouse brain. First, we establish that MCHR1 mRNA is expressed in the ependymal cells of the third ventricle epithelium. Second, we demonstrated a tonic control of $\mathrm{MCH}$-expressing neurons on ependymal cilia beat frequency using in vitro optogenics. Finally, we performed in vivo measurements of CSF flow using fluorescent micro-beads in wild-type and MCHR1-knockout mice. Collectively, our results demonstrated that $\mathrm{MCH}$ expressing neurons modulate ciliary beating of ependymal cells at the third ventricle and could contribute to maintain cerebro-spinal fluid homeostasis.

Keywords: $\mathrm{MCH}, \mathrm{MCHR1}$, non-neuronal function, cilia, CSF flow

\section{INTRODUCTION}

First identified in the early 80 s from chum salmon pituitaries, the melanin concentrating hormone $(\mathrm{MCH})$ draw its name from its capability to induced the concentration of melanin in the skin melanophores (2). However, this function seems to be restricted to teleosts [reviewed in Ref. (3)]. In contrast with high $\mathrm{MCH}$ structural conservation, the neuronal distribution appears quite different, reflecting evolutionary changes in the prosencephalon across vertebrate species (4). In mammals, this cyclic peptide is mainly expressed in neurons of the lateral hypothalamic area (LHA), projecting widely throughout the brain (5); reviewed in Ref. (6). Accordingly, MCH is involved in a broad spectrum of cerebral functions [ for recent reviews, see Ref. $(7,8)$ ]. Nevertheless, all of these seem to converge to the adaptation of global physiologic state to metabolic needs by promoting memory processes and reward pathways activation on one hand and by decreasing arousal and thermogenesis on the other hand. Activation of these cognitive and neuroendocrine networks leads to an increase in food intake and energy storage, respectively [reviewed in Ref. $(9,10)$ ].

The structure of the Pmch gene locus appears to be complex and sense/antisense transcripts could generate different proteinderivatives. Indeed, the precursor ppMCH may be processed mainly, but not exclusively, in two different peptides $(\mathrm{MCH}$ and
$\mathrm{NEI}$ ) in the brain and in several intermediates, including the dipeptide MCH-NEI, in peripheral organs (11-14). An additional protein, named MGOP, may be produced by an alternative splicing of the Pmch gene primary transcript in all cells producing MCH $(15,16)$. Finally a set of proteins, involved in DNA repair, may be synthesized by expression of the AROM/PARI gene located on the complementary strand overlapping the Pmch gene $(8,17)$. Based on this disparity in gene-products expression, it is quite difficult to associate a single molecular substrate responsible to the wide phenotypic changes observed in Pmch gene $\mathrm{KO}$ mice in which the full exon-intron sequences of the Pmch gene as well as the $3^{\prime}$ UTR region of spliced AROM/PARI gene transcripts were deleted. Meanwhile, the issue of developmental compensation (or adaptation) in these genetic models of Pmch gene inactivation should also be considered [see Ref. (9) for discussion of this point].

Efforts to identify the $\mathrm{MCH}$ receptor initially led to the discovery of a spliced variant of the seven-transmembrane G-coupled protein named SLC-1 (18) as a cognate MCH receptor and thereafter referred to as MCHR1 (19-23). MCHR1 is widely localized in brain regions involved in the control of neuroendocrine, reward, motivational, and cognitive aspects of feeding behavior $(9,10,24-$ 26). Interestingly, MCHR1-deficient mice are lean due to hyperactivity and increased metabolism (27). A second $\mathrm{MCH}$ receptor, 
named here MCHR2, was identified and characterized in human tissues and cell lines (27-33). This $\mathrm{MCH}$ receptor displayed a brain distribution that overlapped partially with that of MCHR1 in the primate and fish brain $(32,34)$. However, MCHR2 is lacking in rat and mouse genomes (35). Furthermore, in contrast to MCHR1 that signals to either Gai or Gaq, depending on the transfected or native cell systems, MCHR2 signaling operates apparently exclusively through Gaq protein [our unpublished data; reviewed in Ref. (35-37)].

Based on neuro-anatomical mapping and electrophysiological data, it was assumed that synaptic transmission represents the main mode of action of MCH in the brain. However, non-neuronal intercellular communication or "volume" transmission may also be involved but evidence were lacking. In a recently published study (1), we mapped numerous $\mathrm{MCH}$ fibers in close vicinity to MCHR1 expressed into ependymocytes of the ventral part of the third ventricle $(3 \mathrm{~V})$. Developing new techniques to measure and analyze the ependymal cilia beat frequency (CBF) in acute mouse brain slice preparations, we also showed that the $\mathrm{CBF}$ is increased by $\mathrm{MCH}$ application or LHA stimulation, an effect blocked by a selective MCHR1 antagonist and absent in MCHR1-knockout (MCHR1-KO) mice. In addition, using in vivo brain MRI, we demonstrated that the volume of both the lateral and third ventricles is increased in MCHR1-KO mice compared to their wild-type (WT) littermates. Thus, our study revealed a previously unknown function of the MCH/MCHR1 signaling system in non-neuronal cells. Here, we first demonstrated MCH mRNA expression in the ventral 3V ependymal cells isolated by laser-capture and in situ hybridization. We then extended our previous work, by using in vitro optogenetic activation or inhibition of $\mathrm{MCH}$ neurons. Finally, we investigated in vivo tracking of fluorescent micro-beads through the $3 \mathrm{~V}$ in WT and MCHR1-KO mice. Collectively, we demonstrate a dynamic control of $\mathrm{MCH}$ neurons on spontaneous CBF of MCHR1 mRNA-expressing ependymal cells and discuss the current strategies for measuring CSF flows in small animal models.

\section{MATERIALS AND METHODS \\ ANIMALS}

The experiments were conducted with male C57BL/6J mice (for laser-captured cell mapping, in situ hybridization and cellular optogenetic measurements) and female KO MCHR1 mice (in vivo CSF flow experiments) of 10-12 weeks of age. The animals were obtained from heterozygous breeding in the local animal facilities and maintained on a 12 -h dark/light cycle (7 a.m./7 p.m.) with food and water ad libitum. The MCHR1-KO mice were established as previously described (38).

All the protocols were carried out in accordance with French ethical guidelines for laboratory animals (Agreement $\mathrm{N}^{\circ} 75-178$, 05/16/2000) and were approved by the IPMC care committee. Attention was paid to use only the number of animals requested and necessary to generate reproducible results.

\section{LASER MICRO-DISSECTION OF THIRD VENTRICLE EPITHELIUM}

After decapitation, each brain $(n=2)$ was dissected out in $<2 \mathrm{~min}$ and immediately frozen at $-80^{\circ} \mathrm{C}$ using a Snapfrost (Alphelys, France). Sections (10 $\mu \mathrm{m}$ thick) were cut on a cryostat (Microm
HM 560; object holder and chamber were kept at $\left.-21^{\circ} \mathrm{C}\right)$. Eight sections passing through the posterior hypothalamus were collected on pen membrane slides. Slides, continuously maintained on dry ice, were dehydrated in three baths of increasing ethanol baths $(70,95$, and $100 \%)$ and two baths of fresh xylene (Roth, France) for $5 \mathrm{~min}$ each. Sections were air dried and kept in the vacuum of a dessicator until dissection.

Dissections were performed using a PixCell ${ }^{\circledR}$ (Arcturus Engineering) with CapSure ${ }^{\circledR}$ HS LCM caps. The dissection time never exceeded $20 \mathrm{~min} / \mathrm{slide}$, starting from when the slide was removed from the dessicator. Laser parameters were calibrated for each dissection by measuring the impact of shots on the membrane of the slide adjacent to the tissue. The area of interest was then dissected and laser-captured using UV laser to cut the tissue and IR laser to capture the sample. Four samples were collected per cap (micro-dissection of two slides in $<40 \mathrm{~min}$ in total) and only one cap per brain. As soon as the fourth sample was obtained, the cap was examined under the microscope to ensure the absence of unwanted debris. The sample lysis and the RNA extraction were performed using the RNAqueous ${ }^{\circledR}$-Micro Kit (Ambion, France) following the manufacturer's instructions. The quality of the samples was finally evaluated with the Agilent 2100 Bioanalyzer (Agilent Technology). A rin of 6.1 was twice obtained.

After reverse transcription (Superscript III, Invitrogen), cDNA corresponding to $1 \mathrm{ng}$ of RNA was used as input in a PCR reaction (GoTaq Green MasterMix, Promega, Charbonnières, France) for MCHR1 and HPRT as positive control (MCHR1 F: 5'-GCTCTATGCCAGGCTTATCC-3', MCHR1 R: CAGCTGTCTGAGCATTGCTG-3', amplicon size: 494 bp; HPRT F: CTCCGGAAAGCAGTGAGGTAAG, HPRT R: GGAGGGAGAAAAATGCGGAGTG, amplicon size: $306 \mathrm{bp}$ ). Sample for which reverse transcriptase was omitted was used as negative control. PCR protocol used was designed as follow: initial denaturation: $95^{\circ} \mathrm{C}, 5 \mathrm{~min}$ follow by 40 cycles composed of $95^{\circ} \mathrm{C}, 30 \mathrm{~s}$, $58^{\circ} \mathrm{C}, 30 \mathrm{~s}, 72^{\circ} \mathrm{C}, 1 \mathrm{~min}$, and a final elongation for $7 \mathrm{~min}$ at $72^{\circ} \mathrm{C}$.

\section{IN SITU HYBRIDIZATION}

Frozen sections were post-fixed in $4 \%$ paraformaldehyde in $0.1 \mathrm{M}$ phosphate buffer and digested with proteinase $\mathrm{K}(1 \mu \mathrm{g} / \mathrm{mL}$, Roche $)$ for $30 \mathrm{~min}$ at $37^{\circ} \mathrm{C}$. Slides were incubated for $8 \mathrm{~min}$ in $0.1 \mathrm{M}$ triethanolamine (TEA), $\mathrm{pH} 8.0$, and then for $5 \mathrm{~min}$ at room temperature in $100 \mathrm{~mL} 0.1 \mathrm{M}$ TEA $+500 \mu \mathrm{L}$ acetic anhydride followed by a decarboxylation in active diethyl pyrocarbonate (DEPC).

Sections were then rinsed briefly with $5 \times$ standard citrate sodium (SSC) buffer then incubated for $2 \mathrm{~h}$ in prehybridization buffer at $56^{\circ} \mathrm{C}$. After rinsing in $0.2 \times$ SSC, the sections were incubated overnight at $56^{\circ} \mathrm{C}$, in humid chambers, with $50 \mu \mathrm{L}$ hybridization buffer containing 5\% Denhardt's and 50 ng labeled RNA probes. After rinsing with $5 \times$ SSC, sections were incubated successively in $2 \times \mathrm{SSC}$ at $56^{\circ} \mathrm{C}(1 \mathrm{~h} 30 \mathrm{~min})$ and $0.2 \times$ at room temperature $(5 \mathrm{~min})$. They were incubated in anti-DIG Fab fragments conjugated to alkaline phosphatase (1/1300, overnight) and revealed with enzyme substrate NBT-BCIP (overnight, at room temperature).

Two MCHR1 RNA probes were used; one probe was kindly provided by Drs Civelli and Chung (University of California, Irvine, 
CA, USA) and one made by reverse transcription/polymerase chain reaction from mouse genomic DNA. Control hybridization, including hybridization with sense DIG-labeled riboprobes was realized and did not reveal any signal.

\section{MEASURES OF CILIA BEAT FREQUENCY USING MCH NEURON-SPECIFIC OPTOGENETIC EXCITATION OR INHIBITION}

We have previously shown that electrical stimulation of the LHA induced an increase in the CBF in the $3 \mathrm{~V}$ (1). To further extend and improve the specificity of the response, we used new models allowing the optogenetic control of $\mathrm{MCH}$ neurons activity. All procedures and controls were previously published in (39). Briefly, using cre-dependent Efla-DIO-ChETA-EYFP AAV mediated transduction, the fast mutant of the light-activated Channel rhodopsin-2 (ChETA) or the chloride pump halorhodopsin (NpHR) was specifically expressed in MCH neurons of two different groups of 3 week-old mice. Four weeks after stereotactic injection of the AAV vectors in the LHA (AP: $-1.45 \mathrm{~mm}$, ML: $\pm 1 \mathrm{~mm}, \mathrm{DV}:-5.5 \mathrm{~mm}$ ), brain slices were made and recordings were made in $\mathrm{CBF}$ as described elsewhere (1) before, during, and after stimulation of ChETA-expressing $\mathrm{MCH}$ neurons $(473 \mathrm{~nm}$, stimulation frequency: $1,5,10,20$, and $40 \mathrm{~Hz}$, pulse length: $10 \mathrm{~ms}$, total stimulation duration: $3 \mathrm{~min}$ ) or $\mathrm{NpHR}(590 \mathrm{~nm}$, continuous stimulation during $8.5 \mathrm{~s}$ each $10 \mathrm{~s}, 5 \mathrm{~min}$ ). For each slice and area of recording, the instantaneous $\mathrm{CBF}$ was calculated. All samples in which basal CBF was out of a range comprised between 5 and $20 \mathrm{~Hz}$ (considered as the natural basal frequency in healthy slices) were not included. The mean of the basal frequency during the first $5 \mathrm{~min}$ of recordings were used as a baseline for normalization of the experimental values. Results are expressed as the percentile variation of this baseline.

\section{MEASURE OF CSF FLOW INDEX USING FLUORESCENT MICRO-BEADS}

Littermate controls and female MCHR1-KO mice (aged 12 weeks old) were anesthetized by intraperitoneal injection of ketamine hydrochloride $50 \mathrm{mg} / \mathrm{kg}$ and xylazine $10 \mathrm{mg} / \mathrm{kg}$ and placed in a stereotaxic frame tip of a 26 gage needle was brought to the following coordinates relative to the bregma: $1.75 \mathrm{~mm}$ posterior, $2.5 \mathrm{~mm}$ ventral, and $0 \mathrm{~mm}$ right and left. About $10 \mu \mathrm{L}$ of polystyrene beads (diameter $3 \mu \mathrm{m}$ (sigma L4530) dilution 1:4 in $0.09 \% \mathrm{NaCl}$ ) was injected in the third ventricle.

Fibered confocal fluorescence microscopy (FCFM) (CellviZio; Mauna Kea Technologies, Paris, France) imaging was used to visualize the in vivo movement of the polystyrene beads in the CSF flux. FCFM provides an easy access to these regions of interest with low disturbance of brain structure $(40,41)$. Small-diameter fiber-optic probe consisting of tens of thousands of fibers was implanted in the brain of the mice and connected to a Laser scanning unit LSU-488 (FibroScan) that uses a laser source with a wavelength of $488 \mathrm{~nm}$. We used a MiniZ probe of $300 \mu \mathrm{m}$ diameter with a working distance of $70 \mu \mathrm{m}$. The probe was stereotaxically lowered in the third ventricle at $2.5 \mathrm{~mm}$ ventral. Sensitive, single-pixel detection of fluorescence stimulated by the photodiode laser pulse through each fiber element, combined with the high scan rate allows the visualization of beads movements. Four acquisition sessions of at least $10 \mathrm{~min}$ was recorded for each animal at a frame rate of 11 frames/s.

\section{STATISTICS}

\section{Variation in the $\mathbf{C B F}$}

Statistics were performed using Prism software (Graphpad Inc., La Jolla, CA, USA). The global mean for grouped time points (baseline, stimulation, and recovery) were compared Using One way ANOVA followed by Bonferroni's multiple comparison test (BMCT). $\mathrm{N}=$ number of mice, $\mathrm{n}=$ number of slices, $n=$ number of cells considered. $p$ Value $<0.05$ were considered significant.

\section{Measure of CSF flow index using fluorescent micro-beads}

Movies were visualized on ImageCell ${ }^{\mathrm{TM}}$ viewer. The speed of the beads was analyzed by tracking 10 beads/10 min films. The mean speed for an animal was the mean of the four films speeds. The movies displaying significant modifications of the speed over time were excluded as probably corresponding to pressure due to probe positioning or blood clot.

\section{RESULTS \\ LASER MICRO-DISSECTION OF THIRD VENTRICLE EPITHELIUM AND IN SITU HYBRIDIZATION}

As illustrated in Figures 1A,B; ependymal cell layer was carefully dissected and used for RNA extraction. RT-PCR results indicate that mRNA coding for MCHR1 were present in the $3 \mathrm{~V}$ epithelium (Figure 1C). This was further confirmed by in situ hybridization with two specific probes recognizing MCHR1 mRNA. Indeed, numerous (but not all; see open arrowhead) ependymocytes were labeled with antisense probe (Figure 1D), within the cytoplasm (Figure 1E), while sense probe did not stain any cell types (Figure 1F). These results are in agreement with our immunohistochemical study (1) and recent data from Maratos-Flier's lab using a MCHR1-cre/tdTomato mouse strain (26).

\section{MCH NEURON-SPECIFIC OPTOGENETIC TOOLS}

The ChETA-NpHR system was used to dissect $\mathrm{MCH}$ neuronal circuitry reaching $3 \mathrm{~V}$ ependymal cells and controlling CBF.

The stimulation of ChETA-expressing $\mathrm{MCH}$ neurons in the LHA induces an increase in the CBF reaching $134 \%$ of the basal value (Figures 2A,B; $1 \mathrm{~Hz}, \mathrm{~N}=5, \mathrm{n}=7, n=10, F_{5.069,29}=0.0131$, BMCT: baseline vs. ChETA $t=2.896, p<0.05)$. After $10 \mathrm{~min}$ recovery, the subsequent stimulation at $5 \mathrm{~Hz}$ tended to increase the CBF but did not reach the significance level (Figure 2B; $5 \mathrm{~Hz}, \mathrm{~N}=5, \mathrm{n}=7, n=10$ ). For higher frequencies, no effect was observed (not shown, see Discussion). On the other hand, the stimulation of $\mathrm{NpHR}$ induced a marked decrease in the $\mathrm{CBF}$ reaching $76 \%$ of the basal (Figures $2 \mathrm{C}, \mathrm{D} ; \mathrm{N}=4, \mathrm{n}=8, n=15$, $F_{4.616,44}=0.0154$, BMCT: baseline vs. NpHR $\left.t=3.027, p<0.05\right)$.

\section{MEASURE OF CSF FLOW INDEX USING FLUORESCENT MICRO-BEADS}

In order to address the physiological relevance of $\mathrm{MCH}$-driven ciliary beating regulation, we conducted in vivo flow measure. FCFM imaging was used to visualize the movement of the polystyrene beads in the CSF flux in vivo in groups of WT and $\mathrm{KO}$ MCHR1 mice ( $n=5$ each). The visualization of fluorescent beads movements in the third ventricle allow to approximate the speed of the CSF flux using in vivo brain imagery (Figure 3 ).

Overall, no significant statistical difference in the mean speed between the two groups was found. However, $3 / 5$ animals in the 

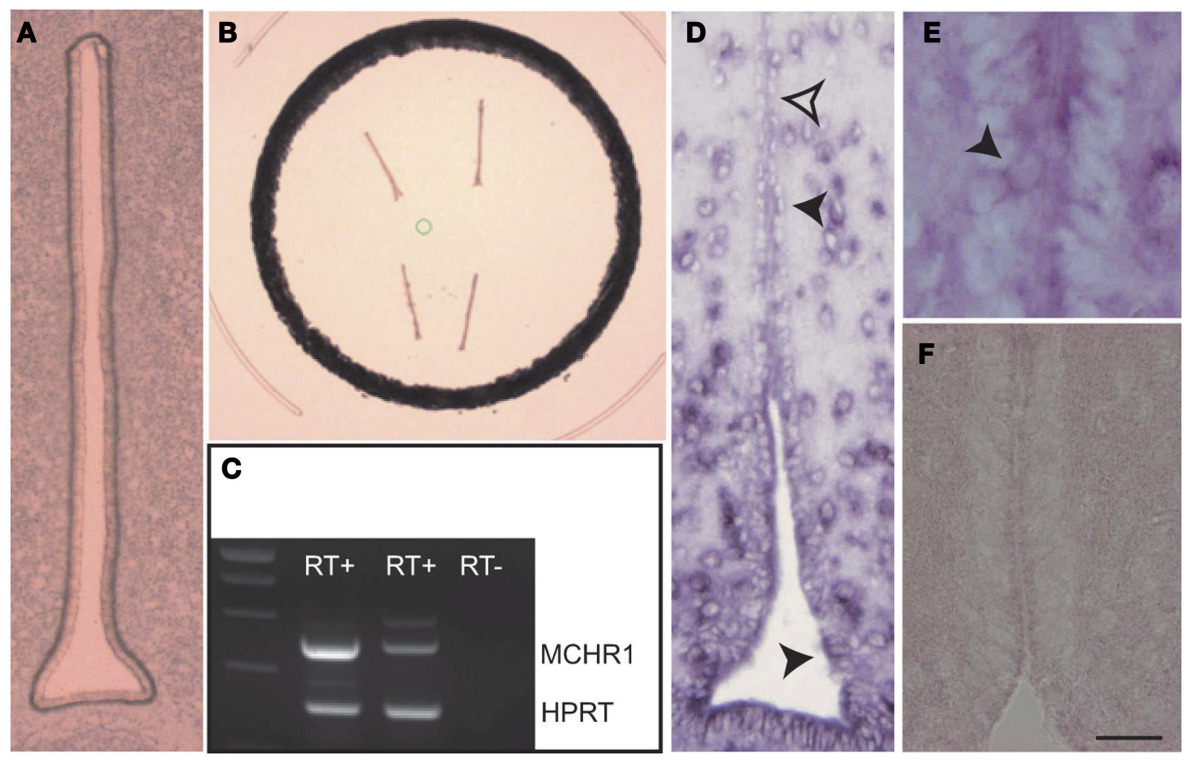

FIGURE 1 | (A) Photomicrograph of the ventricular epithelium before laser micro-dissection. (B) Photomicrograph of the ventricular epithelium after laser micro-dissection. (C) Illustration of the RT-PCR showing the presence of $\mathrm{MCHR} 1 \mathrm{mRNA}$ in the ventricular epithelium. $\mathrm{RT}^{+}$: after reverse transcription, $\mathrm{RT}^{-}$: negative control of the reverse transcription. HPRT: positive control. (D) Photomicrograph to illustrate the distribution of the MCHR1 in situ hybridization signal in the periventricular hypothalamus. Ependymocytes expressed the in situ signal (black arrowheads), but not all of them were labeled (open arrowhead). (E) High magnification to illustrate cytoplasmic expression of MCHR1 mRNA in discrete ependymal cells. (F) A negative control using sense MCHR1 gene probe. Scale bar $=25 \mu \mathrm{m}$ in (A); Scale bar $=20 \mu \mathrm{m}$ in (D); Scale bar $=10 \mu \mathrm{m}$ in (E) and (F).
KO group displayed a twofold increase in the mean speed by comparison with the WT group (that shows consistently low speed). However, it should be stressed that we are measuring the bulk flow driven by the arterio-venous pressure gradients and arterial pulsations and that the laminar flow (close to the ventricle wall and therefore dependent upon cilia beating) remains too small to be measured. Furthermore, we believe that the technical caveat of the implantation of the probe and beads injection in vivo (blood clot, exact position, size of the probe ...) may induce a methodological bias (see Discussion).

\section{DISCUSSION}

The MCH system is involved in a broad spectrum of function through mainly the synaptic release of the peptide(s) and neuronal activity modulation in mammalian brain. However, a growing body of data indicates that MCH may also have non-neuronal function, especially by regulating the activity of more or less specialized peripheral blood mononuclear cells [PBMCs (42)]. The expression of ppMCH and/or MCHR1 genes in pancreatic islets or in adipocytes (43-45) may highlight a metabolism-related function of $\mathrm{MCH}$ at the periphery. Nevertheless, such action may not be totally independent of the intracerebral and/or spinal $\mathrm{MCH}$ pathway (46). Based on our previous study (1) and the present set of data, we demonstrate a new role for the hypothalamic peptide $\mathrm{MCH}$ in modulation of $\mathrm{CBF}$ in the ventral part of the third ventricle through activation of ependymal cells.

In combining the laser micro-dissection of ependymal epithelium of the $3 \mathrm{~V}$ followed by RNA extraction and RT-PCR experiments and in situ hybridization data, we demonstrate the presence of MCHR1 transcripts within the epithelium. This is consistent with the data obtained by immunohistochemistry (1) or in a MCHR1-Cre/tdTomato mouse model (26).

The optogenetic stimulation of the $\mathrm{MCH}$ neurons (through ChETA activation) increased the CBF in the same extend than electrical stimulation did, compared to basal conditions. This confirms also with high temporal precision, the specificity of the response observed in the $3 \mathrm{~V}$. Indeed, only ciliated cells lining the ventral $3 \mathrm{~V}$ that expressed MCHR1 were MCH-sensitive, while those from the dorsal third ventricle or the lateral ventricles were not (1). The spatial specificity of the $\mathrm{MCH}$ response adds a new level of complexity to the previously described characteristics of ciliated ependymal cells [orientation, size, beating mode of cilia along the ventricles $(47,48)]$, and suggests that ciliary beating in cerebral ventricles is fine-tuned to modulate CSF flow in response to metabolic, neurohormonal, and neuroimmune changes. Moreover, our present in situ hybridization experiments, previous immunohistochemical data (1) and mapping using MCHR1-Cre/tdTomato mouse (26) highly suggested a "cluster-like" distribution of the MCHR1 mRNA and proteins along the $3 \mathrm{~V}$. Since adjoining ependymal cells are known to be coupled through GAP junctions (49), it is tempting to speculate that the only few ependymal cells expressing MCHR1 may act as hubs responsible for the effect of $\mathrm{MCH}$ neuronal stimulation on the whole epithelium in the $3 \mathrm{~V}$.

The results obtained following genetic invalidation and pharmacological inactivation of MCHR1 suggested that the $\mathrm{MCH}$ system could exert a tonic positive control on CBF (1). Here, we demonstrate the validity of this hypothesis since the inhibition of $\mathrm{MCH}$ neurons activity (through NpHR stimulation) directly 

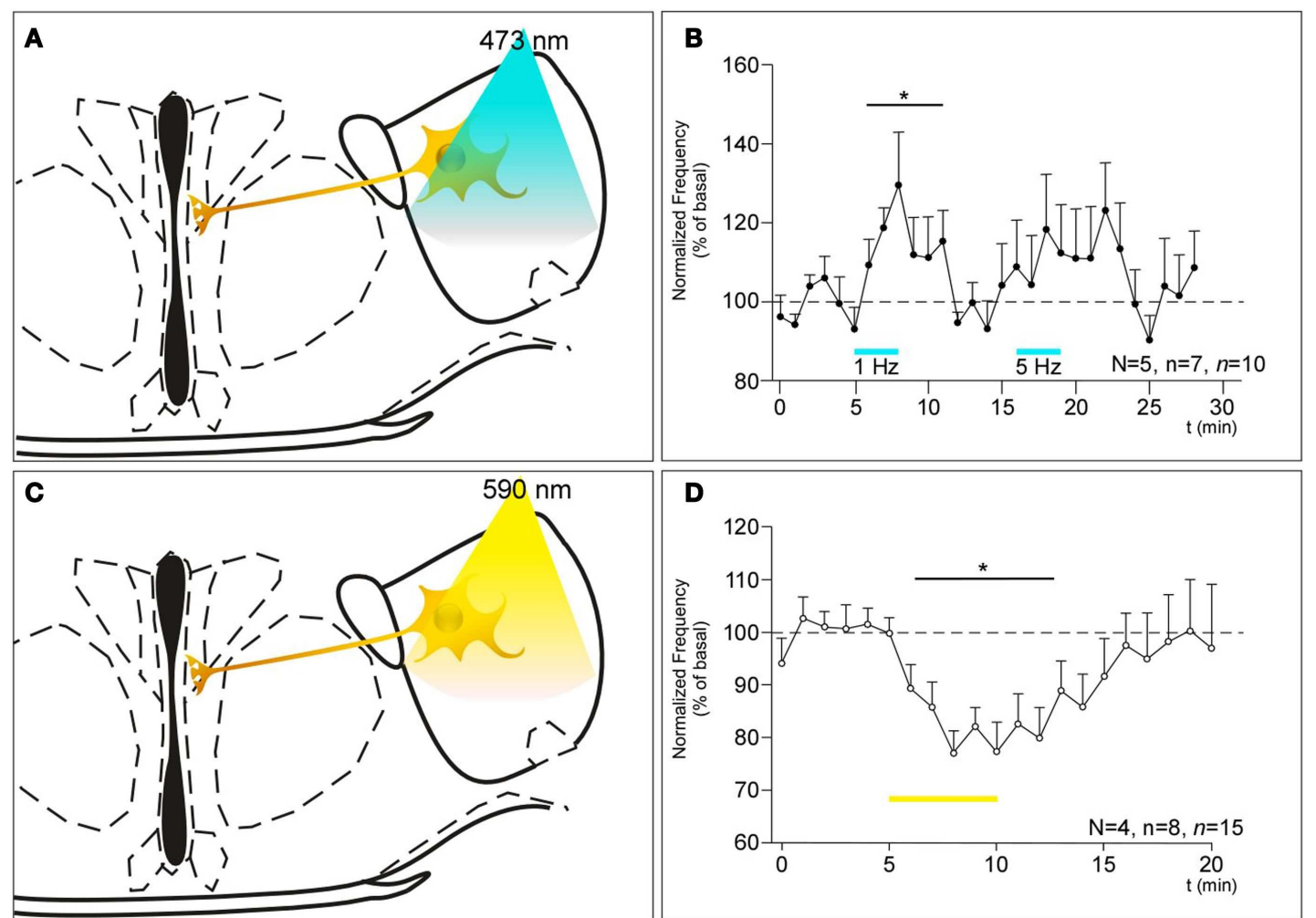

FIGURE 2 | (A,C) Schematics showing the projection of $\mathrm{MCH}$ neurons expressing ChETA (A) or NpHR (C) from the LHA to the ventricular epithelium and their optogenetic stimulation paradigm. (B) Consequences of the stimulation of ChETA in $\mathrm{MCH}$ neurons, by light pulses of $10 \mathrm{~ms}$ at a rate of 1 and $5 \mathrm{~Hz}$ as shown by the bars, on the CBF recorded in the ventral $3 \mathrm{~V}$ expressed as a percentage of the basal frequency. $\mathrm{N}$ : number of animals, $\mathrm{n}$ : numbers of slices, $n$ : number of recording area. ${ }^{*} p<0.05$ (D) Consequences of the stimulation of $\mathrm{NpHR}$ in $\mathrm{MCH}$ neurons as shown by the bars, in $\mathrm{MCH}$ neurons on the CBF recorded in the ventral $3 \mathrm{~V}$. $\mathrm{N}$ : number of animals, $\mathrm{n}$ : numbers of slices, $n$ : number of recording area. affects the CBF. To our knowledge, $\mathrm{MCH}$ is the only known molecule exerting a tonic positive effect on cilia beating in the brain. Even more interestingly, this tonic control of $\mathrm{MCH}$ on the $\mathrm{CBF}$ in the $3 \mathrm{~V}$ does not seem to be compensated through adaptive mechanisms during development, since the basal CBF in MCHR1-KO mice is also reduced (1).

Even if MCH neurons activity seems to be important in the regulation of cilia beating, we have not yet firmly established whether the communication between $\mathrm{MCH}$ neurons and ependymal cells involves a true asymmetric synapse or not. With respect to the anatomical distribution of $\mathrm{MCH}$ fibers around the v3V, the communication should more likely involve passing fibers "leaking" $\mathrm{MCH}$ close to the epithelium basal pole and/or release of the peptide directly into the CSF. Indeed, MCHR1 immunolabeling was observed at both the apex and the basal poles of ciliated ependymal cells as well as MCH fibers crossing the epithelium. The nature of the contacts between ciliated cells and fibers remains to be addressed using a detailed electronic microscopic analysis.

Genetic ablation of MCHR1 results in an increase in the volume of LVs and 3V (both ventral and dorsal) but no change in $4 \mathrm{~V}$ as reported previously (1). In order to determine the flow of CSF using a non-invasive method, we have tried to transpose clinical tools (CINE-MRI) to mice. Unfortunately, the main limit of such technique is the speed of the flow. Preliminary experiments indicate that this speed is $<10 \mu \mathrm{ms}^{-1}$, preventing the use of CINE-MRI in the mouse brain (Kober F., Troalen T., and Viola A. CRMBM. Marseille; personal communication).

The most used methods to study the flow of CSF in rodents consist in the injection of tracers (X-rays or MRI contrast agent) in vivo (50), or the use of fluorescent micro-beads or china ink ex vivo on dissected epithelia (51). Here, we show that it is possible to follow the migration of fluorescent micro-beads through the v3V. Unexpectedly, our data indicate that, in MCHR1-KO mice, the speed of the CSF flow tends to increase as compared to WT littermates, without reaching the statistical significance level. This paradoxical effect could be explained by the Poiseuille's law which postulates a direct link between the mean speed $(V)$ of a viscous liquid (such as CSF) and the radius ( $r$ ) of a small cylinder (such as a ventricle) $\left(V=\mathrm{DP}^{\star} \Pi^{\star} r^{4} / 8 h \times l\right.$ with $h=$ viscosity, $\mathrm{DP}=$ difference of pressure between the extremities of the cylinder, $l=$ length, and $r=$ radius of the cylinder). Indeed, the flow measured at the center of the ventricle would increase when the radius expands. This fits quite well with an enlargement of the ventricle in the KO MCHR1 mice as observed using MRI (1). Another explanation for this discrepancy would be that the optic fiber used for the recording may block the CSF flow in the $3 \mathrm{~V}$ of WT animals but not in MCHR1-KO 


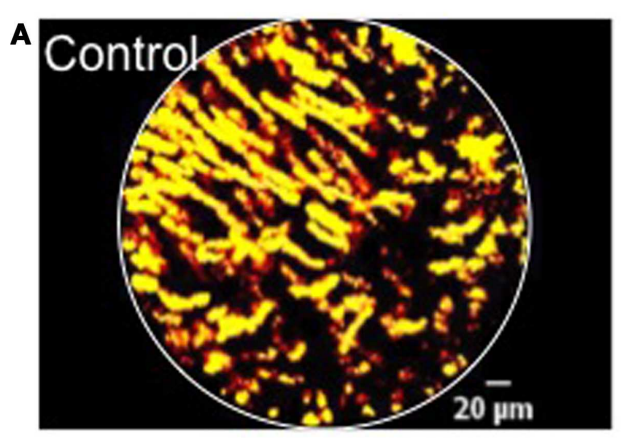

B

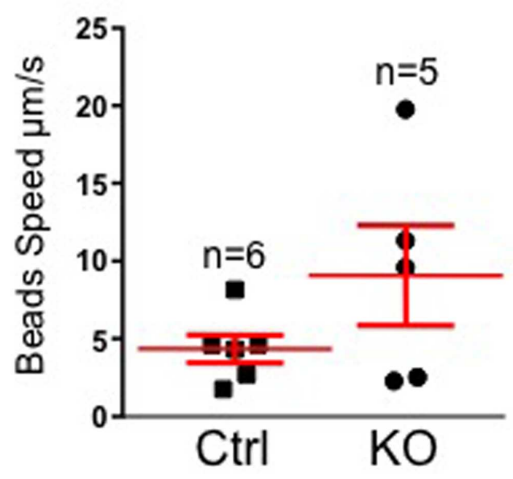

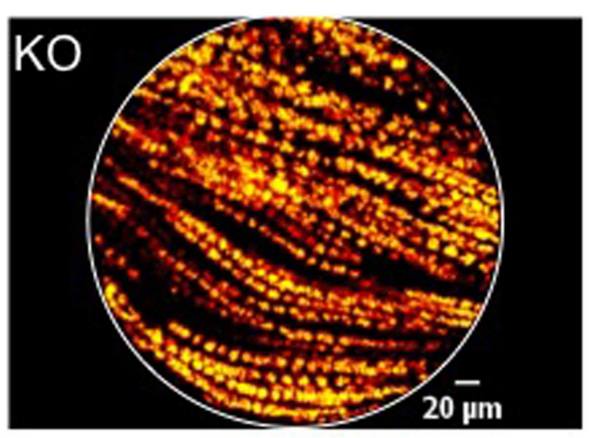

C

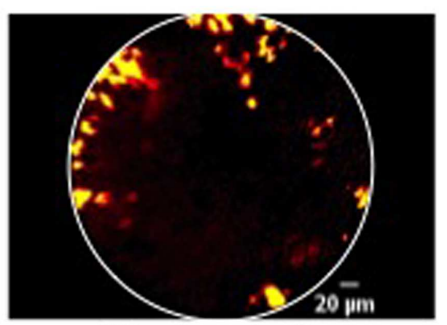

Beads solution

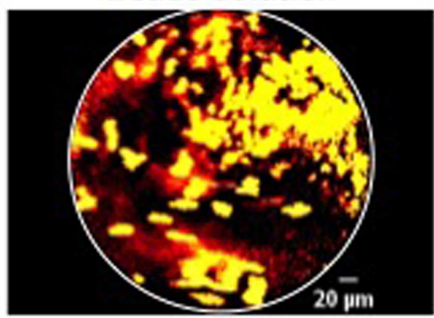

Surface of the brain
FIGURE 3 | (A) Projections of $10 \mathrm{~s}$ acquisition movies illustrating the fluorescent beads movement in the CSF of control (left) and KO MCHR1 (right) animals. In both cases, beads displayed a continuous and orientated movement lasting for at least the recording time. (B) Mean speed of the beads in control and KO MCHR1 animals. (C) Negative controls. Visualizations of fluorescents beads in solution (top) and at the surface of the living brain (bottom). No orientated movements were detected. (since the volume of this ventricle is enlarged in these animals). Moreover, an increase in the CSF pressure into the ventricles could not be excluded.

At this point, it seems important to dissociate the global flow of CSF, mainly resulting from cardio-respiratory activity, to the laminar flow imputable to cilia beating. This point is of prime importance since it has been shown that MCHR1-KO mice display an increase in heart and respiratory rate (52). As a consequence, this may be responsible for the increase in global CSF flow. Moreover, because the volume of the ventricle is increased in MCHR1-KO mice, according to the Poiseuille's equation (see above), the speed of the CSF close to the epithelium should be reduced as compared to what is observed in the center of the ventricle. Because of the cilia action, such an effect is reduced and the speed close to epithelial cells is increased. Thus, in MCHR1-KO mice in which the CBF is altered, an increase in the total CSF flow may compensate the local decrease of the flow at the level of cilia. Taking into account all of these parameters, it is not surprising to observe an increase in CSF speed in the $3 \mathrm{~V}$.
Our data further suggest that motile ciliated cells of the cerebral ventricles are chemosensory as primary cilia, similar to motile ciliate cells from the airway epithelia (53). Hydrocephalus is one of the features of Bardet-Biedl syndrome (BBS), a genetic disease caused by a mutation in one of several proteins involved in the development of primary cilia, BBS1 being the most frequently affected in humans (54). The characteristics of BBS include ventriculomegaly of the lateral and third ventricles, particularly marked in knockin mice expressing the mutated human BBS1 protein (55). As BBS1 is involved in the trafficking of MCHR1 (54), this ventriculomegaly may be partly due to a defect in MCHR1 expression by ciliated ependymal cells, However, it is worth mentioning that the whole distribution of MCHR1 throughout the brain of BBS mouse models is still lacking. The absence of MCHR1 targeting to primary cilium in BBS models does not seems to affect the ciliogenesis (54). In this context, we found no difference in the morphology of the cilia between WT and MCHR1-KO mice, suggesting that MCHR1 does not play an important role in the development of cilia, but only in the modulation of the CBF, once the cilia are 
in place (although some compensatory changes could occur during development). This fits quite well with the characterization of MCHR1 mutants in ciliated hREP1 cells and the discovery of a motif in the third intracellular loop that is mandatory for MCHR1 trafficking to the primary cilia but not ciliogenesis. Other GPCR such as, somatostatin 3 receptor (SST3) and serotonin receptor 6 (5-HTR6) are specifically targeted to the primary cilia. Based on the physiological roles of somatostatin, and since new genetically engineered models such as SST3:Cre - cilia GFP mice (56) have been generated, a complete study about SST involvement in CSF and/or CBF regulation should be considered.

In conclusion, this paper and our previous study (1) point to a new role for $\mathrm{MCH}$ in maintaining CSF flow and homeostasis in the mouse brain. It is worth noting that the main group of $\mathrm{MCH}$ neurons in primitive vertebrates (lampreys) and most fish species (but teleosteans) are located very close (and also projected) to the ventricular surface and could regulate general volume transmission, like in rodents $(4,57)$. This convergent anatomy could be associated with an ancestral function maintained during evolution. Indeed, $\mathrm{MCH}$ neurons could anticipate and initiate the acceleration of CSF circulation, for instance, under conditions of metabolic necessity (glucose withdrawal, fasting, ....). The strategic location of the ciliated cells innervated by $\mathrm{MCH}$ fibers, at the base of the third cerebral ventricle, could allow them to act as a pump to initiate an increase in CSF flow, providing peptides and other messengers to several brain areas and prolonging the effects of these factors in conjunction with neuronal transmission. Moreover, if the same type of CSF flow regulation exists in humans, this work suggests that the chronic administration of brain penetrating MCHR1 antagonists may have long term side effects due to alterations of CSF flows, limiting the probability of their use as therapeutic agents.

\section{AUTHORS CONTRIBUTION}

Grégory Conductier conducted and analyzed brain slice imaging experiments (CBF measurements and optogenetics) and participated to writing. Agnès O. Martin, Chrystel Lafont, and Patrice Mollard performed and analyzed the FCFM experiments, and participated in manuscript writing. Pierre-Yves Risold performed laser-captured, RT-PCR and in situ hybridization experiments. He participates also to writing. Sonia Jego, Raphaël Lavoie, and Antoine Adamantidis performed vector designing and set up the optogenetics experiments, and participated in manuscript writing. Jean-Louis Nahon acquired funding, designed and analyzed experiments, coordinated collaborations, and participated in manuscript writing and editing.

\section{ACKNOWLEDGMENTS}

We warmly thank Dr. Bernard Lakaye of University of Liège (Belgium), for the gift of MCHR1-KO mice and Dr Mounia Annour-Louet for careful reading of the manuscript. We wish to thank Drs Alice Guyon, Frédéric Brau, and Olivier Meste for development and validation of bioinformatics tools, Christophe Houdayer for collecting samples used in lasercaptured experiments, Gabrielle Franchi for help in in situ hybridization, Veronique Thieffin for animal care, Isabelle Larre for help with immunoassays, and Franck Aguila for excellent artwork. We also thank Mauna Kea Technologies (Paris,
France) for providing access to the CellviZio system during the duration of the experiments. Funding sources: this work was funded by the French Government (National Research Agency, ANR) through the "Investments for the Future" LABEX SIGNALIFE:\#ANR-11-LABX-0028-01 (Jean-Louis Nahon), ANR08-MNPS-018-01 (Jean-Louis Nahon), and ANR-2010-BLAN1415-01 (Patrice Mollard), the Centre National de la Recherche Scientifique (PEPS INSB; Jean-Louis Nahon); the sixth FP EU STREPS/NEST-APES Project no. 28594 (Jean-Louis Nahon), the Fondation de la Recherche Médicale (FRM) (Jean-Louis Nahon), the SFR Biocampus de Montpellier (IPAM platform). Financial support: Gregory Conductier was supported by postdoctoral fellowships from the ANR-08-MNPS-018-01 and the Centre National de la Recherche Scientifique (INSB) and by awards from the "Société Française de Nutrition 2011" and the "Institut Danone 2012."

\section{REFERENCES}

1. Conductier G, Brau F, Viola A, Langlet F, Ramkumar N, Dehouck B, et al. Melanin-concentrating hormone regulates beat frequency of ependymal cilia and ventricular volume. Nat Neurosci (2013) 16:845-7. doi:10.1038/nn.3401

2. Rance TA, Baker BI. Possible hypothalamic origin of the teleost melaninconcentrating hormone [proceedings]. J Endocrinol (1979) 81:166.

3. Kawauchi H, Baker BI. Melanin-concentrating hormone signaling systems in fish. Peptides (2004) 25:1577-84. doi:10.1016/j.peptides.2004.03.025

4. Croizier S, Cardot J, Brischoux F, Fellmann D, Griffond B, Risold PY. The vertebrate diencephalic $\mathrm{MCH}$ system: a versatile neuronal population in an evolving brain. Front Neuroendocrinol (2013) 34:65-87. doi:10.1016/j.yfrne. 2012.10.001

5. Bittencourt JC, Presse F, Arias C, Peto C, Vaughan J, Nahon JL, et al. The melaninconcentrating hormone system of the rat brain: an immuno- and hybridization histochemical characterization. J Comp Neurol (1992) 319:218-45. doi:10.1002/ cne. 903190204

6. Bittencourt JC. Anatomical organization of the melanin-concentrating hormone peptide family in the mammalian brain. Gen Comp Endocrinol (2011) 172:185-97. doi:10.1016/j.ygcen.2011.03.028

7. Chung S, Parks GS, Lee C, Civelli O. Recent updates on the melaninconcentrating hormone $(\mathrm{MCH})$ and its receptor system: lessons from $\mathrm{MCH} 1 \mathrm{R}$ antagonists. J Mol Neurosci (2011) 43:115-21. doi:10.1007/s12031-010-9411-4

8. Presse F, Nahon JL. MCH. In: Kastin AJ, editor. Handbook of Biologically Active Peptides. 2nd ed. San Diego, CA: Academic Press (2013). p. 828-37.

9. Pissios P. Animals models of MCH function and what they can tell us about its role in energy balance. Peptides (2009) 30:2040-4. doi:10.1016/j.peptides.2009. 05.002

10. Macneil DJ. The role of melanin-concentrating hormone and its receptors in energy homeostasis. Front Endocrinol (Lausanne) (2013) 4:49. doi:10.3389/ fendo.2013.00049

11. Nahon JL, Presse F, Bittencourt JC, Sawchenko PE, Vale W. The rat melaninconcentrating hormone messenger ribonucleic acid encodes multiple putative neuropeptides coexpressed in the dorsolateral hypothalamus. Endocrinology (1989) 125:2056-65. doi:10.1210/endo-125-4-2056

12. Viale A, Ortola C, Hervieu G, Furuta M, Barbero P, Steiner DF, et al. Cellular localization and role of prohormone convertases in the processing of promelanin concentrating hormone in mammals. J Biol Chem (1999) 274:6536-45. doi:10.1074/jbc.274.10.6536

13. Maulon-Feraille L, Della Zuana O, Suply T, Rovere-Jovene C, Audinot V, Levens N, et al. Appetite-boosting property of pro-melanin-concentrating hormone(131-165) (neuropeptide-glutamic acid-isoleucine) is associated with proteolytic resistance. J Pharmacol Exp Ther (2002) 302:766-73. doi:10.1124/ jpet.302.2.766

14. Sandig H, McDonald J, Gilmour J, Arno M, Lee TH, Cousins DJ. Human Th2 cells selectively express the orexigenic peptide, pro-melanin-concentrating hormone. Proc Natl Acad Sci U S A (2007) 104:12440-4. doi:10.1073/pnas.0705457104

15. Toumaniantz G, Bittencourt JC, Nahon JL. The rat melanin-concentrating hormone gene encodes an additional putative protein in a different reading frame. Endocrinology (1996) 137:4518-21. doi:10.1210/en.137.10.4518 
16. Allaeys I, Bouyer K, Loudes C, Faivre-Bauman A, Petit F, Ortola C, et al. Characterization of $\mathrm{MCH}$-gene-overprinted-polypeptide-immunoreactive material in hypothalamus reveals an inhibitory role of pro-somatostatin1-64 on somatostatin secretion. Eur J Neurosci (2004) 19:925-36. doi:10.1111/j.0953-816X. 2004.03187.x

17. Moldovan GL, Dejsuphong D, Petalcorin MI, Hofmann K, Takeda S, Boulton SJ, et al. Inhibition of homologous recombination by the PCNA-interacting protein PARI. Mol Cell (2012) 45:75-86. doi:10.1016/j.molcel.2011.11.010

18. Kolakowski LF Jr, Jung BP, Nguyen T, Johnson MP, Lynch KR, Cheng R, et al. Characterization of a human gene related to genes encoding somatostatin receptors. FEBS Lett (1996) 398:253-8. doi:10.1016/S0014-5793(96)01160-X

19. Bachner D, Kreienkamp H, Weise C, Buck F, Richter D. Identification of melanin concentrating hormone $(\mathrm{MCH})$ as the natural ligand for the orphan somatostatin-like receptor 1 (SLC-1). FEBS Lett (1999) 457:522-4. doi:10.1016/ S0014-5793(99)01092-3

20. Chambers J, Ames RS, Bergsma D, Muir A, Fitzgerald LR, Hervieu G, et al. Melanin-concentrating hormone is the cognate ligand for the orphan G-proteincoupled receptor SLC-1. Nature (1999) 400:261-5. doi:10.1038/22313

21. Lembo PM, Grazzini E, Cao J, Hubatsch DA, Pelletier M, Hoffert C, et al. The receptor for the orexigenic peptide melanin-concentrating hormone is a G-protein-coupled receptor. Nat Cell Biol (1999) 1:267-71. doi:10.1038/ 12978

22. Saito Y, Nothacker HP, Wang Z, Lin SH, Leslie F, Civelli O. Molecular characterization of the melanin-concentrating-hormone receptor. Nature (1999) 400:265-9. doi:10.1038/22321

23. Shimomura Y, Mori M, Sugo T, Ishibashi Y, Abe M, Kurokawa T, et al. Isolation and identification of melanin-concentrating hormone as the endogenous ligand of the SLC-1 receptor. Biochem Biophys Res Commun (1999) 261:622-6. doi:10.1006/bbrc.1999.1104

24. Kokkotou EG, Tritos NA, Mastaitis JW, Slieker L, Maratos-Flier E. Melaninconcentrating hormone receptor is a target of leptin action in the mouse brain. Endocrinology (2001) 142:680-6. doi:10.1210/en.142.2.680

25. Saito Y, Cheng M, Leslie FM, Civelli O. Expression of the melanin-concentrating hormone $(\mathrm{MCH})$ receptor mRNA in the rat brain. J Comp Neurol (2001) 435:26-40. doi:10.1002/cne.1191

26. Chee MJ, Pissios P, Maratos-Flier E. Neurochemical characterization of neurons expressing melanin-concentrating hormone receptor 1 in the mouse hypothalamus. J Comp Neurol (2013) 521:2208-34. doi:10.1002/cne.23273

27. Marsh DJ, Weingarth DT, Novi DE, Chen HY, Trumbauer ME, Chen AS, et al. Melanin-concentrating hormone 1 receptor-deficient mice are lean, hyperactive, and hyperphagic and have altered metabolism. Proc Natl Acad Sci U S A (2002) 99:3240-5. doi:10.1073/pnas.052706899

28. An S, Cutler G, Zhao JJ, Huang SG, Tian H, Li W, et al. Identification and characterization of a melanin-concentrating hormone receptor. Proc Natl Acad Sci US A (2001) 98:7576-81. doi:10.1073/pnas.131200698

29. Hill J, Duckworth M, Murdock P, Rennie G, Sabido-David C, Ames RS, et al. Molecular cloning and functional characterization of $\mathrm{MCH} 2$, a novel human MCH receptor. J Biol Chem (2001) 276:20125-9. doi:10.1074/jbc. M102068200

30. Mori M, Harada M, Terao Y, Sugo T, Watanabe T, Shimomura Y, et al. Cloning of a novel G protein-coupled receptor, SLT, a subtype of the melanin-concentrating hormone receptor. Biochem Biophys Res Commun (2001) 283:1013-8. doi:10. 1006/bbrc. 2001.4893

31. Rodriguez M, Beauverger P, Naime I, Rique H, Ouvry C, Souchaud S, et al. Cloning and molecular characterization of the novel human melaninconcentrating hormone receptor MCH2. Mol Pharmacol (2001) 60:632-9.

32. Sailer AW, Sano H, Zeng Z, McDonald TP, Pan J, Pong SS, et al. Identification and characterization of a second melanin-concentrating hormone receptor, $\mathrm{MCH}$ 2R. Proc Natl Acad Sci U S A (2001) 98:7564-9. doi:10.1073/pnas.121170598

33. Wang S, Behan J, O’Neill K, Weig B, Fried S, Laz T, et al. Identification and pharmacological characterization of a novel human melanin-concentrating hormone receptor, mch-r2. J Biol Chem (2001) 276:34664-70. doi:10.1074/jbc. M102601200

34. Mizusawa K, Amiya N, Yamaguchi Y, Takabe S, Amano M, Breves JP, et al. Identification of mRNAs coding for mammalian-type melanin-concentrating hormone and its receptors in the scalloped hammerhead shark Sphyrna lewini. Gen Comp Endocrinol (2012) 179:78-87. doi:10.1016/j.ygcen.2012.07.023
35. Tan CP, Sano H, Iwaasa H, Pan J, Sailer AW, Hreniuk DL, et al. Melaninconcentrating hormone receptor subtypes 1 and 2: species-specific gene expression. Genomics (2002) 79:785-92. doi:10.1006/geno.2002.6771

36. Boutin JA, Suply T, Audinot V, Rodriguez M, Beauverger P, Nicolas JP, et al. Melanin-concentrating hormone and its receptors: state of the art. Can J Physiol Pharmacol (2002) 80:388-95. doi:10.1139/y02-056

37. Hervieu G. Melanin-concentrating hormone functions in the nervous system: food intake and stress. Expert Opin Ther Targets (2003) 7:495-511. doi:10.1517/14728222.7.4.495

38. Adamantidis A, Thomas E, Foidart A, Tyhon A, Coumans B, Minet A, et al. Disrupting the melanin-concentrating hormone receptor 1 in mice leads to cognitive deficits and alterations of NMDA receptor function. Eur J Neurosci (2005) 21:2837-44. doi:10.1111/j.1460-9568.2005.04100.x

39. Jego S, Glasgow SD, Herrera CG, Ekstrand M, Reed SJ, Boyce R, et al. Optogenetic identification of a rapid eye movement sleep modulatory circuit in the hypothalamus. Nat Neurosci (2013) 16(11):1637-43. doi:10.1038/nn.3522

40. Vincent P, Maskos U, Charvet I, Bourgeais L, Stoppini L, Leresche N, et al. Live imaging of neural structure and function by fibred fluorescence microscopy. EMBO Rep (2006) 7:1154-61. doi:10.1038/sj.embor.7400801

41. Flusberg BA, Nimmerjahn A, Cocker ED, Mukamel EA, Barretto RP, Ko TH, et al. High-speed, miniaturized fluorescence microscopy in freely moving mice. Nat Methods (2008) 5:935-8. doi:10.1038/nmeth.1256

42. Verlaet M, Adamantidis A, Coumans B, Chanas G, Zorzi W, Heinen E, et al. Human immune cells express ppMCH mRNA and functional MCHR1 receptor. FEBS Lett (2002) 527:205-10. doi:10.1016/S0014-5793(02)03232-5

43. Bradley RL, Kokkotou EG, Maratos-Flier E, Cheatham B. Melanin-concentrating hormone regulates leptin synthesis and secretion in rat adipocytes. Diabetes (2000) 49:1073-7. doi:10.2337/diabetes.49.7.1073

44. Bradley RL, Mansfield JP, Maratos-Flier E, Cheatham B. Melanin-concentrating hormone activates signaling pathways in 3T3-L1 adipocytes. Am J Physiol Endocrinol Metab (2002) 283:E584-92.

45. Pissios P, Ozcan U, Kokkotou E, Okada T, Liew CW, Liu S, et al. Melanin concentrating hormone is a novel regulator of islet function and growth. Diabetes (2007) 56:311-9. doi:10.2337/db06-0708

46. Stanley S, Pinto S, Segal J, Pérez CA, Viale A, DeFalco J, et al. Identification of neuronal subpopulations that project from hypothalamus to both liver and adipose tissue polysynaptically. Proc Natl Acad Sci U S A (2010) 107:7024-9. doi:10.1073/pnas.1002790107

47. Braiman A, Zagoory O, Priel Z. PKA induces Ca2+ release and enhances ciliary beat frequency in a Ca2+-dependent and -independent manner. Am J Physiol (1998) 275:C790-7.

48. Vígh B, Manzano e Silva MJ, Frank CL, Vincze C, Czirok SJ, Szabó A, et al. The system of cerebrospinal fluid-contacting neurons. Its supposed role in the nonsynaptic signal transmission of the brain. Histol Histopathol (2004) 19:607-28.

49. Prochnow N, Dermietzel R. Connexons and cell adhesion: a romantic phase. Histochem Cell Biol (2008) 130:71-7. doi:10.1007/s00418-008-0434-7

50. Sawamoto K, Wichterle H, Gonzalez-Perez O, Cholfin JA, Yamada M, Spassky $\mathrm{N}$, et al. New neurons follow the flow of cerebrospinal fluid in the adult brain. Science (2006) 311:629-32. doi:10.1126/science.1119133

51. Mirzadeh Z, Doetsch F, Sawamoto K, Wichterle H, Alvarez-Buylla A. The subventricular zone en-face: wholemount staining and ependymal flow. J Vis Exp (2010). doi:10.3791/1938

52. Astrand A, Bohlooly-Y M, Larsdotter S, Mahlapuu M, Andersén H, Tornell J, et al. Mice lacking melanin-concentrating hormone receptor 1 demonstrate increased heart rate associated with altered autonomic activity. Am J Physiol Regul Integr Comp Physiol (2004) 287:R749-58. doi:10.1152/ajpregu.00134.2004

53. Shah AS, Ben-Shahar Y, Moninger TO, Kline JN, Welsh MJ. Motile cilia of human airway epithelia are chemosensory. Science (2009) 325:1131-4. doi:10.1126/science.1173869

54. Berbari NF, Lewis JS, Bishop GA, Askwith CC, Mykytyn K. Bardet-Biedl syndrome proteins are required for the localization of $G$ protein-coupled receptors to primary cilia. Proc Natl Acad Sci U S A (2008) 105:4242-6. doi:10.1073/pnas.0711027105

55. Davis RE, Swiderski RE, Rahmouni K, Nishimura DY, Mullins RF, Agassandian $\mathrm{K}$, et al. A knockin mouse model of the Bardet-Biedl syndrome 1 M390R mutation has cilia defects, ventriculomegaly, retinopathy, and obesity. Proc Natl Acad Sci U S A (2007) 104:19422-7. doi:10.1073/pnas.0708571104 
56. O’Connor AK, Malarkey EB, Berbari NF, Croyle MJ, Haycraft CJ, Bell PD, et al. An inducible CiliaGFP mouse model for in vivo visualization and analysis of cilia in live tissue. Cilia (2013) 2:8. doi:10.1186/2046-2530-2-8

57. Bird DJ, Potter IC, Sower SA, Baker BI. The distribution of melaninconcentrating hormone in the lamprey brain. Gen Comp Endocrinol (2001) 121:232-41. doi:10.1006/gcen.2001.7609

Conflict of Interest Statement: The authors declare that the research was conducted in the absence of any commercial or financial relationships that could be construed as a potential conflict of interest.

Received: 13 August 2013; accepted: 07 November 2013; published online: 25 November 2013.
Citation: Conductier G, Martin AO, Risold P-Y, Jego S, Lavoie R, Lafont C, Mollard $P$, Adamantidis A and Nahon J-L (2013) Control of ventricular ciliary beating by the melanin concentrating hormone-expressing neurons of the lateral hypothalamus: $a$ functional imaging survey. Front. Endocrinol. 4:182. doi: 10.3389/fendo.2013.00182

This article was submitted to Neuroendocrine Science, a section of the journal Frontiers in Endocrinology.

Copyright (C) 2013 Conductier, Martin, Risold, Jego, Lavoie, Lafont, Mollard, Adamantidis and Nahon. This is an open-access article distributed under the terms of the Creative Commons Attribution License (CC BY). The use, distribution or reproduction in other forums is permitted, provided the original author(s) or licensor are credited and that the original publication in this journal is cited, in accordance with accepted academic practice. No use, distribution or reproduction is permitted which does not comply with these terms. 